\title{
Plant-plant interactions could limit recruitment and range expansion of tall shrubs into alpine and Arctic tundra
}

\author{
Sandra Angers-Blondin ${ }^{1,2}$ (1) Isla H. Myers-Smith ${ }^{1}\left[\right.$ [ Stéphane Boudreau ${ }^{2}$ (i)
}

Received: 19 December 2017 / Revised: 19 May 2018 / Accepted: 6 June 2018 / Published online: 16 June 2018

(c) The Author(s) 2018

\begin{abstract}
Species in cold-limited biomes are expected to expand their distribution ranges in response to climate warming. For plants, range shifts can only occur via successful recruitment beyond their current distribution limit. However, many environmental and ecological filters can act upon recruitment and establishment, thereby potentially limiting the expected climate-driven shifts. In this study, we investigate potential mechanical and chemical constraints that vegetation above the tall shrubline in alpine and Arctic tundra could impose upon the successful establishment of willow species in the Canadian Western Arctic. We collected willow seeds from an alpine and an Arctic shrubline and conducted germination trials to test (1) for seedbed preferences among three natural and one experimentally scarified seedbeds, and (2) for vulnerability to allelopathic chemicals produced by ericaceous dwarf shrub species. We found that germination was almost four times higher on manually exposed bare ground than on intact, herbaceous vegetation. Seeds of two willow species, Salix arctica and Salix pulchra, were not affected by leaf extracts from dwarf shrubs, Cassiope tetragona and Vaccinum uliginosum, but the germination of Salix richardsonii was reduced by as much as $24 \%$ in the presence of chemicals from C. tetragona. Our results suggest that biotic interactions could limit the predicted expansion of tall shrubs in the tundra by interfering with germination. Seemingly species-specific responses highlight the need for replicated studies across a wider range of species combinations. Potential range shifts may not occur as a uniform translocation of the shrubline, but could change the composition of the plant community by filtering out certain species.
\end{abstract}

Keywords Allelopathy $\cdot$ Seedbed $\cdot$ Germination $\cdot$ Seedlings $\cdot$ Shrubline $\cdot$ Tundra

\section{Introduction}

Ecosystem boundaries are in part controlled by temperature, and have shifted with past variations in climate as species migrated to track their climatic optimum (Davis and Shaw 2001). Under the current rapid rates of warming at the global scale (IPCC 2013), latitudinal or elevational advances in distribution limits have recently been observed in most taxa including invertebrates, plants, birds, and mammals (Chen et al. 2011). In tundra ecosystems, tall shrub species are projected to expand their range up mountain slopes and

Sandra Angers-Blondin

s.angers-blondin@ed.ac.uk

1 School of GeoSciences, University of Edinburgh, The King's Buildings, Edinburgh EH9 3FF, UK

2 Centre d'Études Nordiques, Université Laval, Pavillon Abitibi-Price, 2405 rue de la Terrasse, Quebec, QC G1V 0A6, Canada northward to higher latitudes (Post et al. 2009; Myers-Smith et al. 2011).

In sessile species such as plants, range shifts occur via the recruitment and establishment of new individuals beyond the current distribution limit. Because of the multiple environmental and ecological filters acting on regeneration (Fig. 1), these shifts are spatially heterogeneous and often lag changes in climate (Corlett and Westcott 2013; Ash et al. 2016). For instance, treelines have only advanced in around half of the sites studied in a global meta-analysis (Harsch et al. 2009). Similarly, although tundra shrubs have been expanding in the circumpolar region over the last half-century (Myers-Smith et al. 2011), most of the observed increases in growth and reproduction have only led to population infilling, and range shifts remain mostly anecdotal (but see Myers-Smith and Hik 2017). Some of the non-climatic limitations interfering with range expansion may include species traits like dispersal ability (Brooker et al. 2007; Kambo and Danby 


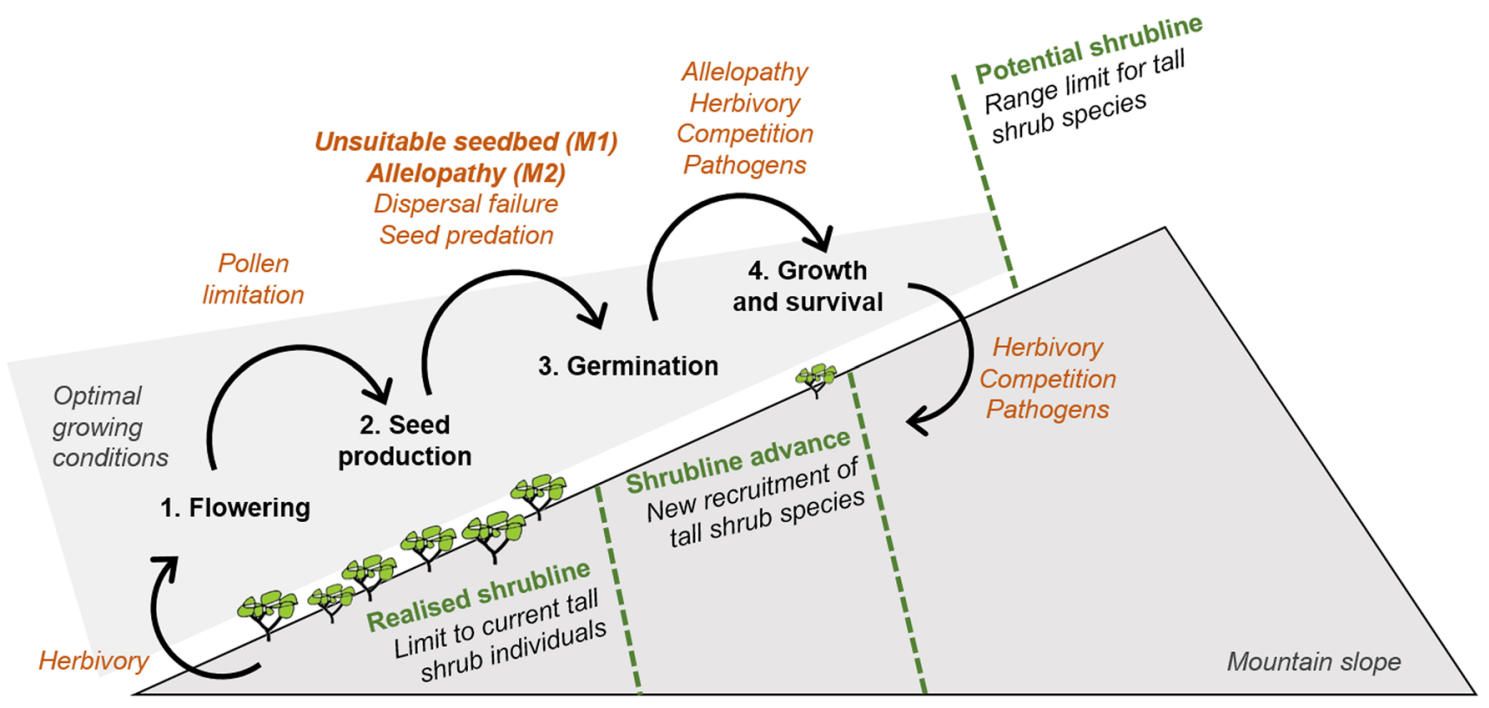

Fig. 1 Biological constraints (orange) potentially acting as ecological filters on the process of regeneration (green) above the shrubline with the mechanisms of seedbeds (mechanism 1) and allelopathy (mechanism 2) highlighted in bold, the foci of this study. (Color figure online)

2017), and a wide range of biotic interactions (reviewed in HilleRisLambers et al. 2013).

Species interactions are affected by climate change, and in turn control community assembly in environments where new species could meet their temperature requirements (Tylianakis et al. 2008; Gilman et al. 2010; Van der Putten et al. 2010). In plant communities, interactions with herbivores (Olofsson et al. 2009; Munier et al. 2010; Christie et al. 2015), soil biota (Van Grunsven et al. 2007), pathogens (Olofsson et al. 2011) and other plants (Grau et al. 2012; Liang et al. 2016) may all promote or constrain range shifts. It is therefore critical to better understand biotic interactions and incorporate them in species distribution models (Brooker et al. 2007; Hellmann et al. 2012; Meier et al. 2012).

In addition to direct competition for resources, several other types of plant-plant interactions can interfere with the establishment of a species beyond its current range. The vegetation already in place can prevent seeds from reaching a suitable seedbed. For instance, conifers at the treeline have been shown to become preferentially established after disturbance exposing the bare ground (Dufour Tremblay and Boudreau 2011). In addition, vegetation may chemically interfere with seed germination when allelopathic species are present. Allelopathy is the production of toxic compounds by some plants; when leached into the ground, these chemicals can affect the germination, growth, and survival of other species (Wardle et al. 1998). For example, some conifer seeds and seedlings are vulnerable to chemicals released by ericaceous dwarf shrubs (Nilsson and Zackrisson 1992; Dufour Tremblay et al. 2012). It is currently unknown whether these biotic controls of treeline dynamics act similarly upon shrublines at higher latitudes and elevations.

To investigate whether plant-plant interactions have the potential to limit range shifts of tall shrubs into the tundra, we carried out germination experiments using seeds of widespread and rapidly expanding willow species (Salix spp.) collected from an Arctic and an alpine shrubline in the Yukon Territory. Our research question was the following: Does vegetation above the tall shrubline affect the germination of shrub seeds? We experimentally tested two potential mechanisms of interference: (1) vegetation acts as a physical barrier preventing shrub seeds from reaching a suitable seedbed (M1 in Fig. 1); and (2) chemicals released by ericaceous dwarf shrubs inhibit germination (M2 in Fig. 1). Correspondingly, we predicted (1) that seeds of the tall willow shrub, Salix pulchra Cham. would germinate to a higher extent on bare ground than on vegetated ground, and (2) that seeds of the tall willows S. pulchra and Salix richardsonii Hooker and of the dwarf willow Salix arctica Pall., would germinate to a lesser extent when exposed to potentially allelopathic leachates from the ericaceous dwarf shrubs, Vaccinium uliginosum L. And Cassiope tetragona (L.) D. Don.

\section{Materials and methods}

\section{Study sites}

We conducted two germination experiments (scarification and allelopathy) on Qikiqtaruk-Herschel Island $\left(69.568^{\circ} \mathrm{N}\right.$, $\left.138.918^{\circ} \mathrm{W}\right)$, a Yukon territorial park in Northern Canada. 
The allelopathy experiment was replicated in the Kluane region of the Southwest Yukon Territory $\left(61.027^{\circ} \mathrm{N}\right.$, $138.411^{\circ} \mathrm{W}$, Fig. 2). These two sites are $1000 \mathrm{~km}$ apart and represent both Arctic and alpine tundra ecosystems where tall shrubs are thought to be expanding their ranges.

Qikiqtaruk is underlain by ice-rich permafrost (Burn and Zhang 2009) and harbours several types of tundra vegetation (described by Smith et al. 1989), including the Herschel type characterised by moist acidic tussock tundra, and the Komakuk type comprising herbaceous tundra disturbed by freeze-thaw processes. Alpine habitats of the Kluane Region are underlain by bedrock containing permafrost. The alpine zone is characterised by willow-dominated tall shrub tundra transitioning to dwarf shrub and herbaceous tundra at around 1600-1900 m elevation (Myers-Smith 2011).

On Qikiqtaruk, both experiments were set up in front of a window in an unheated warehouse. The average daily minimum, mean and maximum temperatures during the 10 days spanning both experiments were $7.4 / 12.0 / 18.0{ }^{\circ} \mathrm{C}$, respectively, measured by iButton Thermochron data loggers $\left( \pm 1{ }^{\circ} \mathrm{C}\right.$, model DS1921G-F5, Dallas Semiconductor Corporation, Dallas, TX, USA) with hourly recording. In Kluane, the allelopathy experiment was set up in a laboratory (average daily minimum, mean and maximum temperatures were $18.9 / 21.0 / 24.1{ }^{\circ} \mathrm{C}$, respectively, measured as above over 9 days). A scarification experiment was initially also set up in Kluane, but coincided with a week of unusually high temperatures. The laboratory not being climate controlled, this resulted in the seedlings drying out and dying within $48 \mathrm{~h}$ after emerging, and the experiment was discontinued.

\section{Study species}

Salix pulchra and Salix richardsonii are willow species with an erect growth form. They are widespread in the Western Arctic and dominant species at our study sites; on Qikiqtaruk, they approximately reach their northern distribution limit (Argus 2007). Salix arctica is a dwarf willow widely distributed in the circumpolar region all the way up to the High Arctic, over $80^{\circ} \mathrm{N}$ (Argus 2007). It is a dominant species on Qikiqtaruk and could therefore greatly contribute to woody plant encroachment there. However, germination of this species is highly variable both spatially and temporally, and thus expansion could be limited by regeneration failures (Boulanger-Lapointe et al. 2016). This is why we included this species in the experiment despite it being far from its leading range edge. Willows are capable of spreading clonally, but while this certainly contributes to the infilling of existing populations (Myers-Smith et al. 2011), colonisation of new sites in a range shift context requires establishment from seed. Willows tend to be early-successional plants characterised by fast growth rates (Bret-Harte et al. 2002) and the production of great numbers of small, wind-dispersed seeds that can recolonize sites rapidly after disturbances (Brinkman 1974; Forbes et al. 2001).

Vaccinium uliginosum, a blueberry, is an ericaceous deciduous dwarf shrub known to have allelopathic effects on conifer seeds (Dufour Tremblay et al. 2012). Cassiope tetragona is an ericaceous evergreen dwarf shrub for which no allelopathic effects have yet been reported; however, it has been shown to interfere with the growth of Arctic

Allelopathy experiments

Scarification experiment

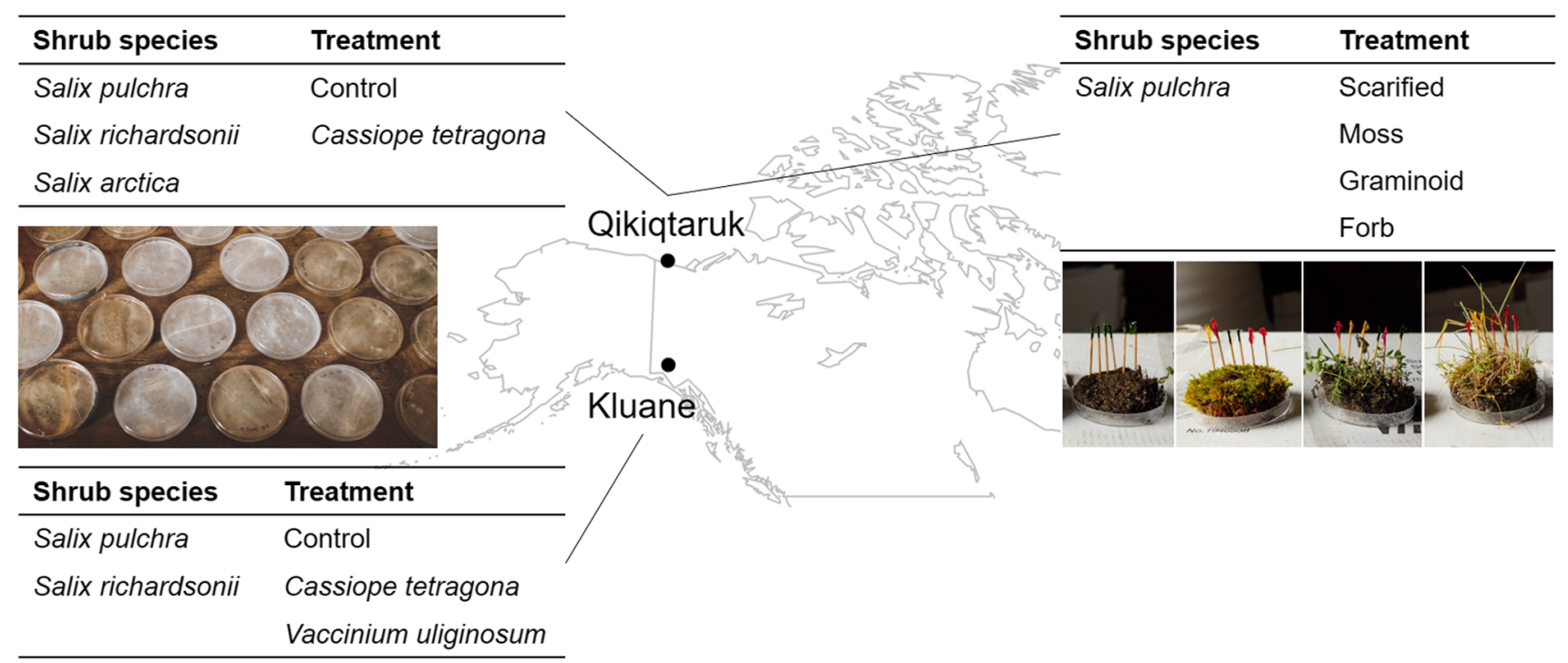

Fig. 2 Location of the two field sites in the Western Canadian Arctic and details of the experiments carried out at each research station using seeds from local shrubline tundra sites 
graminoids (Michelsen et al. 2012). These dwarf shrubs typically come in later during succession (Lambert 1972) and have higher investments in reproduction and defences.

\section{Scarification experiment}

Our first objective was to test whether seedbed type influenced willow germination. The four seedbeds tested were (1) moss-dominated; (2) grass-dominated; (3) forb-dominated; and (4) scarified. For each treatment, we collected four discs (10 cm diameter, ca. $3 \mathrm{~cm}$ deep) of undisturbed tundra vegetation on Qikiqtaruk. Cover of the target vegetation type for the moss, grass and forb treatments was over $90 \%$ on each disc. For the scarified discs, we randomly collected discs with a mixed cover of grasses and forbs and carefully stripped them of all above-ground vegetation to expose the organic soil. Samples were collected in a ca. 50-m-by-50-m plot on a south-facing ridge belonging to the Komakuk vegetation type (Smith et al. 1989) and brought back to the warehouse.

Catkins of Salix pulchra were collected at a nearby site. Only ripe catkins were collected, and no more than 10 catkins per individual shrub were harvested to reduce genetic bias. Seeds were all pooled together before sowing on the discs.

On all discs, 36 seeds were sown in a six-by-six arrangement, with a toothpick marking the emplacement of each row to facilitate monitoring. The discs were misted twice daily with a spray-bottle containing distilled water to prevent seeds from drying. Emergence was monitored daily until no further germination occurred.

\section{Allelopathy experiment}

Our second objective was to test whether willow seeds were vulnerable to potentially toxic compounds leached from the leaves of two ericaceous dwarf shrubs. Allelopathy experiments were run at both field sites (Fig. 2). In the alpine shrub tundra of Printer's Pass (Ruby Range mountains, Kluane), we collected ca. 200 ripe catkins of S. pulchra and S. richardsonii following the sampling protocol described in the previous section. Around $100 \mathrm{~g}$ of fresh leaves of Vaccinium uliginosum and Cassiope tetragona were collected in the same area. Leachates were prepared by soaking $75 \mathrm{~g}$ of leaves in $500 \mathrm{~mL}$ of distilled water for $24 \mathrm{~h}$ to obtain a $15 \%$ solution (Dufour Tremblay et al. 2012).

On Qikiqtaruk, around 150 catkins were collected for S. pulchra, S. richardsonii and S. arctica. As V. uliginosum is not locally abundant, we only used a leachate of $C$. tetragona in this experiment. The leaf extract was prepared as described above.

Seeds were sown on filter paper in 9-mm Petri dishes ( 25 seeds per dish in Kluane; 50 seeds per dish on Herschel
Island). At the start of the experiment, $3 \mathrm{~mL}$ of either leaf extract (C. tetragona or $V$. uliginosum) or distilled water (control treatment) were put in every dish. We added $2 \mathrm{~mL}$ of the same treatments the following day, then kept all dishes moist as needed with distilled water for the duration of the experiment. In Kluane, we set up eight replicate dishes of the factorial design (all combinations of species and treatments). On Qikiqtaruk, we set up four replicate dishes. The dishes were spatially randomised and rotated daily to avoid spatial effects. We monitored emergence daily until no further germination occurred.

\section{Statistical analyses}

Analyses were conducted using generalised linear models with a binomial distribution (logit link function) to account for germination rates being constrained between 0 and 1 . Germination rates were not zero-inflated. For the scarification experiment, which was conducted with a single species, we used seedbed as the explanatory variable. For the allelopathy experiments, we ran separate models for the two study locations, using treatment (control, V. uliginosum extract, $C$. tetragona extract) and willow species as interacting explanatory variables. When means differed significantly among treatments, we conducted Tukey's post hoc tests using the "lsmeans" package. All analyses were conducted in R v. 3.3.2 (R Core Team 2016).

\section{Results}

\section{Scarification experiment}

Emergence of Salix pulchra was significantly higher on scarified ground than on forb- or grass-dominated ground, and intermediate on moss-covered ground (Fig. 3; Table 1A). Germination started within $24 \mathrm{~h}$ of sowing and ceased after 4 days.

\section{Allelopathy experiment}

On Qikiqtaruk (Fig. 4a; Table 1B), S. pulchra and S. richardsonii had high and similar germination rates, but the germination of $S$. richardsonii was reduced in the presence of C. tetragona leaf extract, while that of S. pulchra was not. Salix arctica experienced much lower germination that was not affected by the allelopathic treatment.

In Kluane (Fig. 4b; Table 1C), the germination of S. richardsonii was slightly lower than that of S. pulchra, and like on Qikiqtaruk, was reduced in the presence of $C$. tetragona leaf extract compared to the control. Extract of $V$. uliginosum had no effect on either S. richardsonii or S. pulchra. 


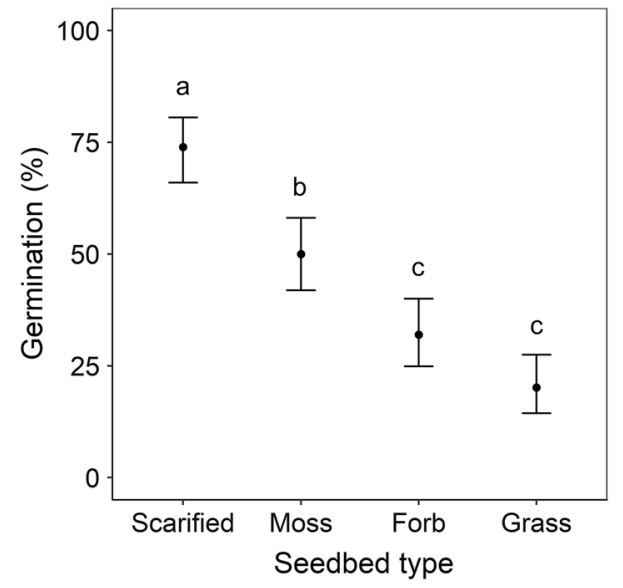

Fig. 3 Germination of Salix pulchra presenting higher on scarified ground than on forb- or grass-covered ground, and intermediate on moss. Dots represent binomial model estimates (error bars are $95 \%$ confidence intervals), and letters indicate significant differences between treatments, as identified by Tukey's post hoc test

\section{Discussion}

In this study, we demonstrated that willow seeds preferentially germinated on bare ground. Moreover, our experiments revealed a potential vulnerability of some shrub species to chemical interference from ericaceous dwarf shrubs. Together, these findings have implications for expected range shifts and community composition changes under climate warming. Our results suggest that the community already in place above the shrubline may physically or chemically impede shrub recruitment. Biotic interactions are likely to shape future vegetation trajectories in the tundra, and it is critical to gain a better understanding of the mechanisms involved to predict more accurately future range expansion of shrub species.

\section{Scarification experiment}

Willows are pioneer species in boreal and tundra succession, producing a large number of small seeds that can be winddispersed over long distances and rapidly colonise disturbed sites (Walker et al. 1986). Our dedicated germination study found that emergence of willow seedlings was higher on bare ground than on ground covered by herbaceous vegetation, supporting succession theory. These results also agree with observations of higher abundance and performance of shrubs on ground disturbed by thermokarst processes (Lantz et al. 2009). More widely, our results align with treeline studies that have shown increased conifer recruitment on exposed mineral soil (Dufour Tremblay and Boudreau 2011). Few similar experiments have been conducted with shrub species, but our results are in accordance with those of Graae et al.
Table 1 Model outputs from binomial logistic regressions to explain germination of tundra willows as a function of (A) ground layer composition and (B-C) allelopathic effects of ericaceous dwarf shrubs at two field sites

\begin{tabular}{|c|c|c|c|c|}
\hline & Estimate & SE & $z$ value & $p$ \\
\hline \multicolumn{5}{|l|}{ (A) Scarification-Qikiqtaruk } \\
\hline Scarified (intercept) & 1.04 & 0.19 & 5.37 & $<0.0001$ \\
\hline Moss & -1.04 & 0.26 & -4.07 & $<0.0001$ \\
\hline Forb & -1.80 & 0.26 & -6.82 & $<0.0001$ \\
\hline Grass & -2.42 & 0.28 & -8.51 & $<0.0001$ \\
\hline Contrasts & & \multicolumn{3}{|c|}{ z ratio } \\
\hline Scarified-moss & 1.04 & 0.26 & 4.07 & 0.0003 \\
\hline Scarified—forb & 1.80 & 0.26 & 6.82 & $<0.0001$ \\
\hline Scarified_grass & 2.42 & 0.28 & 8.51 & $<0.0001$ \\
\hline Moss_forb & 0.76 & 0.24 & 3.10 & 0.0106 \\
\hline Moss—grass & 1.38 & 0.27 & 5.17 & $<0.0001$ \\
\hline Forb—grass & 0.62 & 0.27 & 2.27 & 0.1058 \\
\hline \multicolumn{5}{|l|}{ Sample size: 16} \\
\hline \multicolumn{5}{|l|}{ Null deviance: 156.15 on $15 \mathrm{df}$} \\
\hline \multicolumn{5}{|l|}{ Residual deviance: 58.21 on $12 \mathrm{df}$} \\
\hline \multicolumn{5}{|l|}{ (B) Allelopathy—Qikiqtaruk } \\
\hline Intercept & 0.87 & 0.16 & 5.62 & $<0.0001$ \\
\hline TreatmentCAS & 0.31 & 0.23 & 1.36 & 0.1747 \\
\hline SpeciesSR & -0.02 & 0.22 & -0.11 & 0.9130 \\
\hline SpeciesSA & -2.23 & 0.23 & -9.52 & $<0.0001$ \\
\hline TreatmentCAS:SpeciesSR & -0.94 & 0.31 & -3.02 & 0.0025 \\
\hline TreatmentCAS:SpeciesSA & -0.16 & 0.33 & -0.49 & 0.6263 \\
\hline Contrasts & & \multicolumn{3}{|c|}{ z ratio } \\
\hline SP: C-CAS & -0.31 & 0.23 & -1.36 & 0.1747 \\
\hline SR: C-CAS & 0.62 & 0.21 & 2.98 & 0.0028 \\
\hline SA: C-CAS & -0.15 & 0.24 & -0.61 & 0.5447 \\
\hline \multicolumn{5}{|l|}{ Sample size: 24} \\
\hline \multicolumn{5}{|l|}{ Null deviance: 298.185 on $23 \mathrm{df}$} \\
\hline \multirow{2}{*}{\multicolumn{5}{|c|}{$\begin{array}{l}\text { Residual deviance: } 36.565 \text { on } 18 \mathrm{df} \\
\text { (C) Allelopathy_Kluane }\end{array}$}} \\
\hline & & & & \\
\hline Intercept & 0.10 & 0.16 & 6.25 & $<0.0001$ \\
\hline TreatmentCAS & -0.26 & 0.22 & -1.20 & 0.2294 \\
\hline TreatmentVAC & -0.46 & 0.21 & -2.14 & 0.0326 \\
\hline SpeciesSR & -0.85 & 0.21 & -4.01 & $<0.0001$ \\
\hline TreatmentCAS:SpeciesS R & -0.24 & 0.30 & -0.81 & 0.4200 \\
\hline TreatmentVAC:SpeciesSR & 0.12 & 0.30 & 0.41 & 0.6806 \\
\hline \multicolumn{2}{|l|}{ Contrasts } & \multicolumn{3}{|c|}{ z ratio } \\
\hline SP: C-CAS & 0.50 & 0.22 & 1.20 & 0.4521 \\
\hline SP: C-VAC & 0.46 & 0.22 & 2.14 & 0.0825 \\
\hline SP: CAS-VAS & -0.16 & 0.21 & 0.95 & 0.6120 \\
\hline SR: C-CAS & 0.50 & 0.20 & 2.50 & 0.0335 \\
\hline SR: C-VAC & 0.34 & 0.20 & 1.70 & 0.2059 \\
\hline SR: CAS-VAC & -0.16 & 0.20 & -0.81 & 0.6982 \\
\hline \multicolumn{5}{|l|}{ Sample size: 48} \\
\hline \multicolumn{5}{|l|}{ Null deviance: 110.254 on $47 \mathrm{df}$} \\
\hline Residual deviance: 42.834 on $42 \mathrm{df}$ & & & & \\
\hline
\end{tabular}

Species codes are SP Salix pulchra, SR: Salix richardsonii, SA Salix arctica. Allelopathic treatments are coded $C$ for control, $C A S$ for Cassiope tetragona leachate, and VAC for Vaccinium uliginosum leachate. For each model, pairwise post hoc contrasts are presented using Tukey's post hoc test, and significant contrasts are bolded 

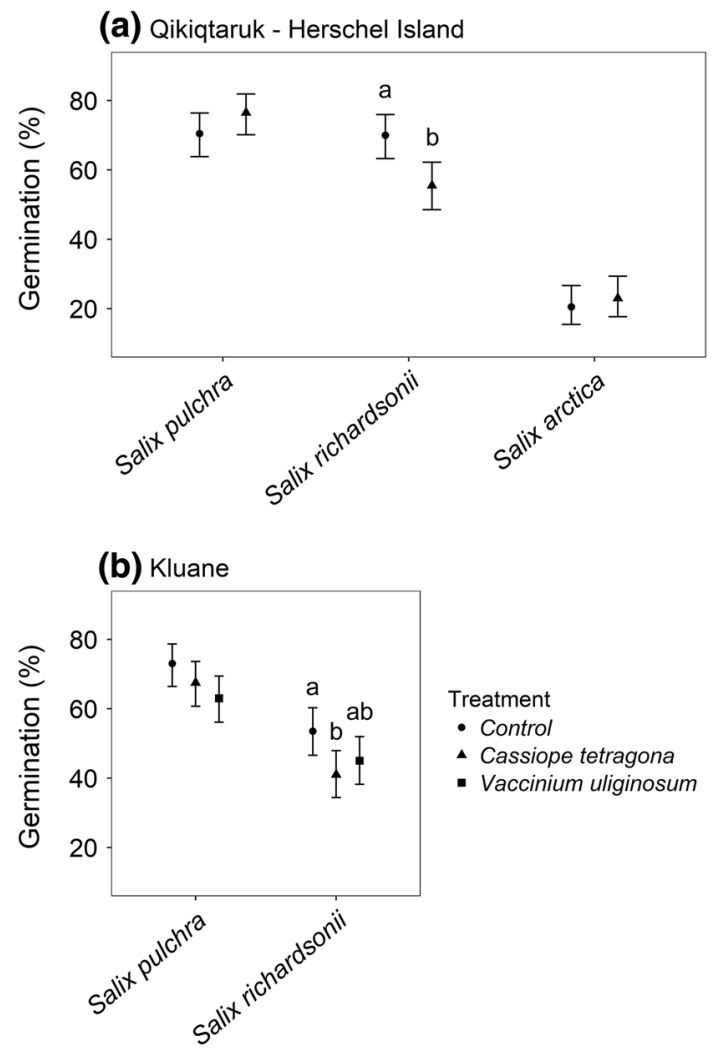

Fig. 4 Effect of leaf extracts from Cassiope tetragona and Vaccinium uliginosum on seed germination of three willow species from a Qikiqtaruk and b Kluane. Dots represent binomial model estimates (error bars are confidence intervals), and letters indicate significant differences between treatments, as identified by Tukey's post hoc test

(2011), who found consistently higher germination of tundra species on bare ground.

Willows typically produce short-lived seeds that must germinate within a few days of ripening (Bliss 1958; Brinkman 1974). It therefore seems likely that when seeds are dispersed on dense, tall vegetation, they cannot always reach the ground and meet their moisture requirement for germinating, and rapidly lose viability. On the contrary, seeds that fall onto bare ground can germinate within a day, as we observed during this study. We found that the moss seedbed had intermediate rates of germination, which could be due to high water retention capacity compared to herbaceous vegetation. In stressful environments, mosses can facilitate recruitment by sheltering seedlings from herbivores and temperature extremes (Wheeler et al. 2011; Lett et al. 2017).

We cannot generalise our observations to all tundra shrub species, as it is likely that species-specific traits like seed longevity play an important role in these interactions. Nonetheless, our results suggest that vegetation above the shrubline might act as a physical barrier for establishment of some dominant tundra shrub species. In a context of vegetation encroachment and decrease in bare ground at our field site (Myers-Smith et al. in review), and in the tundra biome in general (Elmendorf et al. 2012), there might be limited opportunities for shrubline advance. This could lead to an increasing reliance on disturbance for regeneration (Lantz et al. 2010; Frost et al. 2013) as optimal recruitment microsites become sparser.

\section{Allelopathy experiment}

At both sites, the germination of Salix richardsonii was reduced when seeds were exposed to $C$. tetragona leaf extracts. In addition to producing allelopathic compounds, ericaceous species can change soil nutrient status and chemical properties (Bloom and Mallik 2006). Previously, negative effects of $C$. tetragona on the growth of graminoids have been explained by the labile carbon in the extracts promoting nutrient uptake by soil biota, thereby depleting resources for plants (Michelsen et al. 1995). As our seeds were placed directly on sterile filter paper without the possibility of thirdparty interactions, our results suggest that the leaves of $C$. tetragona may contain allelopathic compounds affecting the germination of some species. Alternatively, other chemical properties of the solution, such as reduced $\mathrm{pH}$, could have affected germination. Edaphic factors are important in controlling shrub distribution: for instance, Salix pulchra is more tolerant to acidic soils than S. richardsonii (Swanson 2015). More work will be needed to validate our findings and identify the precise mechanism of interference. The very low germination of Salix arctica is unsurprising: unlike the other two species, it is a late disperser with conditionally dormant seeds (Densmore and Zasada 1983).

All three of our focal research species are found at the shrubline in the Kluane region (Myers-Smith and Hik 2017) and are widely distributed on Qikiqtaruk (Smith et al. 1989), yet they each have different habitat preferences. Interestingly, Salix richardsonii is spatially segregated from $C$. tetragona on Qikiqtaruk, the former being typically associated with other canopy-forming willows, and the latter mostly found with other evergreen shrubs and Betula nana in the Komakuk vegetation type characterised by soil disturbance from freeze-thaw processes (Smith et al. 1989). These habitat preferences likely reflect the different tolerance and plasticity of willow species to soil characteristics and other environmental and succession-related characteristics: throughout the Yukon Territory, Salix richardsonii is most commonly found on alluvial sites or floodplains, while Salix pulchra has a wider range of habitats (Cody 1996). The higher environmental plasticity of $S$. pulchra might be partially linked to the apparent absence of vulnerability to chemical interference from common ericaceous dwarf shrubs, although further studies will be required to test this specifically. 
The fact that only one out of three willow species seemed vulnerable to allelopathy raises the issue of replication in this study and the question of the specificity of biotic interactions. Species-specific allelopathic responses have been reported at the treeline, with for instance black spruce, but not larch, being affected by ericaceous species (Dufour Tremblay et al. 2012). However, the scarcity of similar studies and low sample sizes make it difficult to rule out experimental artefacts and identify general patterns. To validate our findings and make them more generally applicable to the tundra biome, we call for more tests of allelopathic effects with these and other species in the Arctic region.

\section{Biotic filters for shrubline expansion}

While shrub encroachment in the tundra biome has received considerable attention, shrublines are understudied, with only six studies focusing specifically on range shifts (reviewed in Myers-Smith and Hik 2017). A study of 14 elevational shrublines in the Kluane region, one of our field sites, consistently found younger willows at higher elevations, a pattern suggestive of climate-driven range expansion (Myers-Smith and Hik 2017). However, we still have a poor understanding of the local factors that may mitigate the speed of shrubline advances. Our results and the lack of comparable studies highlight the need to better understand plant-plant interactions within tundra communities. Standardised replication of our experiments at more sites and with a more diverse range of tundra species could help determine whether biotic interactions are likely to be a major constraint to shrub expansion above the shrubline.

The biotic interactions investigated in this study, i.e. interaction with ground cover and allelopathy, are only a subset of all the possible interactions that may affect seedling establishment above the shrubline. Notably, below-ground interactions in the tundra are still poorly understood, and it is unclear whether some positive associations, like those arising from mycorrhizal symbionts and other interactions with soil microbiota (Grau et al. 2010; Pellissier et al. 2013; Sedlacek et al. 2014), may balance out negative interactions like allelopathy. The growth and survival of seedlings could be positively or negatively affected by the presence of taller plants through nurse effects or competition, respectively: the direction and importance of these interactions can even vary across life-stages (e.g. seed-seedling conflicts; Cranston and Hermanutz, 2013).

Overall, the realised extent of range shifts depends not only on climate suitability but also on biotic interactions within the new community (HilleRisLambers et al. 2013). Therefore, range shifts of Arctic and alpine shrublines will almost certainly be slower than predicted by climate envelope models. The species-specific nature of biotic interactions may act as an ecological filter where the advance of some species may be limited or prevented by the presence of competitors, allelopathic plants, or selective herbivores. Thus, it is unlikely that tundra shrubline range shifts will occur as intact plant communities moving to higher elevations or latitudes; instead, filtering will occur, with biotic interactions leading to different species assemblages forming beyond the current range limit.

\section{Conclusion}

Climate change is altering ecosystem boundaries, and a growing research focus is to achieve the integration of biotic interactions into predictive models of climate-driven range shifts. While treelines have received extensive attention and the effects of a wider range of plant-plant interactions on recruitment are starting to be better understood, it is unclear whether those mechanisms have the same importance at high-elevation and high-latitude shrublines. Our two simple experiments showed that the effects of two types of plant-plant interactions, namely seedbed type and allelopathy, are also relevant processes partly limiting germination at and above Arctic and alpine shrublines. Acknowledging the high spatio-temporal variability in seed production and viability in northern environments, we call for replication of these types of studies to gain a better understanding of the constraints acting upon regeneration in the tundra biome.

Acknowledgements The authors thank John Godlee for assistance in the field. The authors also thank the Qikiqtaruk-Herschel Island Territorial Park rangers, the Aurora Research Institute, and Sian and Lance Williams for their logistical support. The authors are grateful to the Kluane First Nation and the Inuvialuit People for the opportunity to conduct this research in their traditional territories. Inspiration for the scarification experiment came from stimulating discussions with the G-TREE working group (http://treelineresearch.com). Funding was provided by the Natural Science and Engineering Research Council of Canada (NSERC), the UK Natural Environment Research Council (NERC), and the Canadian Centennial Scholarship Fund.

Author Contributions S.A.B. designed the study with inputs from all authors. S.A.B. and I.M.S. conducted the experiments. S.A.B. analysed the data. S.A.B. wrote the manuscript with inputs from all authors.

\section{Compliance with Ethical Standards}

Conflict of interest The authors declare that they have no conflict of interest.

Open Access This article is distributed under the terms of the Creative Commons Attribution 4.0 International License (http://creativeco mmons.org/licenses/by/4.0/), which permits unrestricted use, distribution, and reproduction in any medium, provided you give appropriate credit to the original author(s) and the source, provide a link to the Creative Commons license, and indicate if changes were made. 


\section{References}

Argus GW (2007) Salix (Salicaceae) distribution maps and a synopsis of their classification in North America, north of Mexico. HPB 12:335-368

Ash JD, Givnish TJ, Waller DM (2016) Tracking lags in historical plant species' shifts in relation to regional climate change. Glob Change Biol 23:1305-1315

Bliss LC (1958) Seed germination in Arctic and alpine species. Arctic 11:180-188

Bloom RG, Mallik AU (2006) Relationships between ericaceous vegetation and soil nutrient status in a post-fire Kalmia angustifoliablack spruce chronosequence. Plant Soil 289:211-226

Boulanger-Lapointe N, Lévesque E, Baittinger C, Schmidt NM (2016) Local variability in growth and reproduction of Salix arctica in the High Arctic. Polar Res 35:24126

Bret-Harte MS, Shaver GR, Chapin FS (2002) Primary and secondary stem growth in Arctic shrubs: implications for community response to environmental change. J Ecol 90:251-267

Brinkman KA (1974) Salix L. willow. In: Schopmeyer, CS (technical coordinator). Seeds of woody plants in the United States. Agriculture Handbook. 450. Department of Agriculture, Forest Service, Washington, DC, pp 746-750

Brooker RW, Travis JMJ, Clark EJ, Dytham C (2007) Modelling species' range shifts in a changing climate: the impacts of biotic interactions, dispersal distance and the rate of climate change. $\mathrm{J}$ Theor Biol 245:59-65

Burn CR, Zhang Y (2009) Permafrost and climate change at Herschel Island (Qikiqtaruq), Yukon Territory, Canada. J Geophys Res 114:1-16

Chen IC, Hill JK, Ohlemüller R, Roy DB, Thomas CD (2011) Rapid range shifts of species associated with high levels of climate warming. Science 333:1024-1026

Christie KS, Bryant JP, Gough L, Ravolainen VT, Ruess RW, Tape KD (2015) The role of vertebrate herbivores in regulating shrub expansion in the Arctic: a synthesis. BioScience 65:1123-1133

Cody WJ (1996) Flora of the Yukon Territory. NRC Research Press, Ottawa

Corlett RT, Westcott DA (2013) Will plant movements keep up with climate change? Trends Ecol Evol 28:482-488

Cranston BH, Hermanutz L (2013) Seed-seedling conflict in conifers as a result of plant-plant interactions at the forest-tundra ecotone. Plant Ecol Divers 6:319-327

Davis MB, Shaw RG (2001) Range shifts and adaptive responses to Quaternary climate change. Science 292:673-679

Densmore R, Zasada J (1983) Seed dispersal and dormancy patterns in northern willows: ecological and evolutionary significance. Can J Bot 61:3207-3216

Dufour Tremblay G, Boudreau S (2011) Black spruce regeneration at the treeline ecotone: synergistic impacts of climate change and caribou activity. Can J For Res 41:460-468

Dufour Tremblay G, De Vriendt L, Levesque E, Boudreau S (2012) The importance of ecological constraints on the control of multispecies treeline dynamics in eastern Nunavik, Quebec. Am J Bot 99:1638-1646

Elmendorf SC, Henry GH, Hollister RD, Björk RG, BoulangerLapointe N, Cooper EJ, Cornelissen JH et al (2012) Plot-scale evidence of tundra vegetation change and links to recent summer warming. Nat Clim Change 2:453-457

Forbes BC, Ebersole JJ, Strandberg B (2001) Anthropogenic disturbance and patch dynamics in circumpolar Arctic ecosystems. Conserv Biol 15:954-969

Frost GV, Epstein HE, Walker DA, Matyshak G, Ermokhina K (2013) Patterned-ground facilitates shrub expansion in Low Arctic tundra. Environ Res Lett 8:1-9
Gilman SE, Urban MC, Tewksbury J, Gilchrist GW, Holt RD (2010) A framework for community interactions under climate change. Trends Ecol Evol 25:325-331

Graae BJ, Ejrnæs R, Lang SI, Meineri E, Ibarra PT, Bruun HH (2011) Strong microsite control of seedling recruitment in tundra. Oecol 166:565-576

Grau O, Rautio P, Heikkinen J, Saravesi K, Kozlov MV, Markkola A (2010) An ericoid shrub plays a dual role in recruiting both pines and their fungal symbionts along primary succession gradients. Oikos 119:1727-1734

Grau O, Ninot JM, Blanco-Moreno JM, van Logtestijn RSP, Cornelissen JHC, Callaghan TV (2012) Shrub-tree interactions and environmental changes drive treeline dynamics in the Subarctic. Oikos 121:1680-1690

Harsch MA, Hulme PE, McGlone MS, Duncan RP (2009) Are treelines advancing? A global meta-analysis of treeline response to climate warming. Ecol Lett 12:1040-1049

Hellmann JJ, Prior KM, Pelini SL (2012) The influence of species interactions on geographic range change under climate change. Ann N Y Acad Sci 1249:18-28

HilleRisLambers J, Harsch MA, Ettinger AK, Ford KR, Theobald EJ (2013) How will biotic interactions influence climate changeinduced range shifts? Ann N Y Acad Sci 1297:112-125

IPCC (2013) Climate Change 2013: the physical science basis. In: Stocker TF, Qin D, Plattner GK, Tignor M, Allen SK, Boschung J, Nauels A, Xia Y, Bex V, Midgley PM (eds) Contribution of Working Group I to the Fifth Assessment Report of the Intergovernmental Panel on Climate Change. Cambridge University Press, Cambridge

Kambo D, Danby RK (2017) Constraints on treeline advance in a warming climate: a test of the reproduction limitation hypothesis. J Plant Ecol 9:1-17

Lambert JDH (1972) Plant succession on tundra mudflows: preliminary observations. Arctic 25:99-106

Lantz TC, Kokelj SV, Gergel SE, Henry GHR (2009) Relative impacts of disturbance and temperature: persistent changes in microenvironment and vegetation in retrogressive thaw slumps. Glob Change Biol 15:1664-1675

Lantz TC, Gergel SE, Henry GHR (2010) Response of green alder (Alnus viridis subsp. fruticosa) patch dynamics and plant community composition to fire and regional temperature in northwestern Canada. J Biogeogr 37:1597-1610

Lett S, Nilsson MC, Wardle DA, Dorrepaal E (2017) Bryophyte traits explain climate-warming effects on tree seedling establishment. J Ecol 105:496-506

Liang E, Wang Y, Piao S, Lu X, Camarero JJ, Zhu H, Zhu L, Ellison AM, Ciais P, Peñuelas J (2016) Species interactions slow warming-induced upward shifts of treelines on the Tibetan Plateau. Proc Natl Acad Sci USA 113:4380-4385

Meier ES, Lischke H, Schmatz DR, Zimmermann NE (2012) Climate, competition and connectivity affect future migration and ranges of European trees. Glob Ecol Biogeogr 21:164-178

Michelsen A, Schmidt IK, Jonasson S, Dighton J, Jones HE, Callaghan TV (1995) Inhibition of growth, and effects on nutrient uptake of arctic graminoids by leaf extracts-allelopathy or resource competition between plants and microbes? Oecol 103:407-418

Michelsen A, Rinnan R, Jonasson S (2012) Two decades of experimental manipulations of heaths and forest understory in the Subarctic. Ambio 41:218-230

Munier A, Hermanutz L, Jacobs JD, Lewis K (2010) The interacting effects of temperature, ground disturbance, and herbivory on seedling establishment: implications for treeline advance with climate warming. Plant Ecol 210:19-30

Myers-Smith IH (2011) Shrub encroachment in arctic and alpine tundra: Patterns of expansion and ecosystem impacts. $\mathrm{PhD}$ 
dissertation, Department of Biological Sciences, University of Alberta, Edmonton, Canada

Myers-Smith IH, Hik DS (2017) Climate warming as a driver of tundra shrubline advance. J Ecol 106:547-560

Myers-Smith IH, Forbes BC, Wilmking M, Hallinger M, Lantz T, Blok D, Tape KD et al (2011) Shrub expansion in tundra ecosystems: dynamics, impacts and research priorities. Environ Res Lett 6:1-15

Nilsson MC, Zackrisson O (1992) Inhibition of Scots pine seedling establishment by Empetrum hermaphroditum. J Chem Ecol 18:1857-1870

Olofsson J, Oksanen L, Callaghan T, Hulme PE, Oksanen T, Suominen O (2009) Herbivores inhibit climate-driven shrub expansion on the tundra. Glob Change Biol 15:2681-2693

Olofsson J, Ericson L, Torp M, Stark S, Baxter R (2011) Carbon balance of Arctic tundra under increased snow cover mediated by a plant pathogen. Nat Clim Change 1:220-223

Pellissier L, Pinto-Figueroa E, Niculita-Hirzel H, Moora M, Villard L, Goudet J, Guex N et al (2013) Plant species distributions along environmental gradients: do belowground interactions with fungi matter? Front in Plant Sci 4:1-9

Post E, Forchhammer MC, Bret-Harte MS, Callaghan TV, Christensen TR, Elberling B, Fox AD et al (2009) Ecological dynamics across the Arctic associated with recent climate change. Science 325:1355-1358

R Core Team (2016) R: a language and environment for statistical computing. R Foundation for Statistical Computing, Vienna, Austria. http://www.R-project.org/
Sedlacek JF, Bossdorf O, Cortés AJ, Wheeler JA, van Kleunen M (2014) What role do plant-soil interactions play in the habitat suitability and potential range expansion of the alpine dwarf shrub Salix herbacea? Basic Appl Ecol 15:305-315

Smith CAS, Kennedy CE, Hargrave AE, McKenna KM (1989) Soil and vegetation of Herschel Island. Research Branch, Agriculture Canada, Ottawa

Swanson DK (2015) Environmental limits of tall shrubs in Alaska's Arctic national parks. PLoS ONE 10:1-34

Tylianakis JM, Didham RK, Bascompte J, Wardle DA (2008) Global change and species interactions in terrestrial ecosystems. Ecol Lett 11:1351-1363

Van der Putten WH, Macel M, Visser ME (2010) Predicting species distribution and abundance responses to climate change: why it is essential to include biotic interactions across trophic levels. Philos Trans R Soc B 365:2025-2034

Van Grunsven RHA, Van Der Putten WH, Bezemer TM, Tamis WLM, Berendse F, Veenendaal EM (2007) Reduced plant-soil feedback of plant species expanding their range as compared to natives. $\mathbf{J}$ Ecol 95:1050-1057

Walker LR, Zasada JC, Chapin FS (1986) The role of life history processes in primary succession on an Alaskan floodplain. Ecology 67:1243-1253

Wardle DA, Nilsson MC, Gallet C, Zackrisson O (1998) An ecosystemlevel perspective of allelopathy. Biol Rev 73:305-319

Wheeler JA, Hermanutz L, Marino PM (2011) Feathermoss seedbeds facilitate black spruce seedling recruitment in the forest-tundra ecotone (Labrador, Canada). Oikos 120:1263-1271 